\title{
PENINGKATAN KETUNTASAN BELAJAR MATAKULIAH FISIKA INTI MAHASISWA PRODI PENDIDIKAN FISIKA IKIP PGRI MADIUN MELALUI KEGIATAN LESSON STUDY
}

\author{
Farida Huriawati $^{1)}$, Jeffry Handhika ${ }^{1,2)}$, Erawan Kurniadi ${ }^{1,3)}$ \\ ${ }^{1}$ Prodi Pendidikan Fisika IKIP PGRI Madiun \\ Email: frd21pfisae@gmail.com \\ ${ }^{1,2}$ Prodi pendidikan Fisika IKIP PGRI Madiun \\ Email: jeffry.handhika@yahoo.com \\ ${ }^{1,3}$ Prodi pendidikan Fisika IKIP PGRI Madiun \\ Email: erawan.kurniadi@yahoo.com
}

\begin{abstract}
Abstrak
Berdasarkan data tentang prestasi belajar mahasiswa untuk matakuliah Fisika Inti mempunyai ketuntasan belajar 65\% dengan nilai ketuntasan 65 . Ketuntasan belajar mahasiswa juga ditentukan oleh keprofesionalan dosen dalam melaksanakan kegiatan perkuliahan. Untuk itu setiap dosen diharapkan selalu merencanakan pembelajaran, merefleksi pembelajaran yang telah dilakukan dan kemudian merencanakan perbaikan untuk pembelajaran berikutnya yang dilakukan secara terus menerus. Kegiatan perencanaan, pelaksanaan, dan refleksi pembelajaran akan lebih baik jika dilakukan secara kolaboratif di antara dosen matakuliah serumpun. Hal ini sesuai dengan prinsip-prinsip Lesson Study (Sumar Hendayana,dkk.: 2006: 20). Dari latar belakang di atas maka dapat dirumuskan masalah sebagai berikut: Apakah kegiatan Lesson Study dapat meningkatkan ketuntasan belajar Fisika Inti bagi mahasiswa program studi pendidikan Fisika? Untuk memperjelas rumusan masalah tersebut, perlu diajukan pertanyaan-pertanyaan penelitian sebagai berikut: (1) Bagaimanakah interaksi mahasiswa-mahasiswa, mahasiswa-dosen, dosen-dosen dalam kegiatan Lesson Study pada matakuliah Fisika Inti? (2) Bagaimanakah pengelolaan pembelajaran Fisika Inti oleh dosen dalam mengimplementasikan Lesson Study? (3) Bagaimanakah ketuntasan belajar Fisika Inti bagi mahasiswa program studi pendidikan Fisika dengan mengimplementasikan Lesson Study?. Tujuan Penelitian (1) Mendeskripsikan interaksi mahasiswa-mahasiswa, mahasiswadosen, dosen-dosen dalam kegiatan Lesson Study pada matakuliah Fisika Inti. (2) Mendeskripsikan pengelolaan pembelajaran Fisika Inti oleh dosen dalam mengimplementasikan Lesson Study. (3) Mendeskripsikan ketuntasan belajar Fisika Inti bagi mahasiswa program studi pendidikan Fisika dengan mengimplementasikan Lesson Study. Adapun manfaat penelitian ini adalah: (1) Dosen dapat memilih bentuk kegiatan yang menunjang keprofesionalannya melalui Lesson Study. (2) Sebagai masukan bagi dosen lain bahwa Lesson Study dapat meningkatkan aktivitas dan ketuntasan belajar mahasiswa. (3) Dapat terjalin kerjasama antar dosen matakuliah serumpun (kolegalitas), meningkatkan penguasaan materi dan cara pembelajarannya. Hasil penelitian: a) terjadinya interaksi yang efektif antara mahasiswa-mahasiswa, mahasiswa-dosen dan mahasiswa dengan lingkungan belajar, ini berarti pengelolaan pembelajaran oleh dosen lebih baik dari sebelumnya, dan (b) sebagai akibatnya ketuntasan belajar mahasiswa meningkat menjadi $75 \%$.
\end{abstract}

Kata Kunci: Lesson Study, Fisika Inti, Ketuntasan Belajar

\section{PENDAHULUAN}

Pada pembelajaran mata kuliah fisika inti menawarkan beberapa tantangan yang besar bagi para pendidiknya. Pada mata kuliah fisika inti sejumlah besar materi sangat luas dan bersifat abstrak. Selain itu materi juga harus mampu disampaikan secara cepat kepada mahasiswa. Materi yang bersifat abstrak memberikan kendala pada proses pemahaman terhadap materi kuliah fisika inti dan akibatnya mahasiswa tidak mampu secara cepat menyerap materi dalam perkuliahan.

Berdasarkan data tentang prestasi belajar mahasiswa untuk matakuliah Fisika Inti mempunyai ketuntasan belajar 63,8\% dengan nilai ketuntasan 65. Ketuntasan belajar mahasiswa juga ditentukan oleh keprofesionalan dosen 
dalam melaksanakan kegiatan perkuliahan. Untuk itu setiap dosen diharapkan selalu merencanakan pembelajaran, merefleksi pembelajaran yang telah dilakukan dan kemudian merencanakan perbaikan untuk pembelajaran berikutnya yang dilakukan secara terus menerus. Kegiatan perencanaan, pelaksanaan, dan refleksi pembelajaran akan lebih baik jika dilakukan secara kolaboratif di antara dosen matakuliah serumpun. Hal ini sesuai dengan prinsip-prinsip Lesson Study (Sumar Hendayana,dkk.: 2006: 20). Dari latar belakang di atas maka dapat dirumuskan masalah sebagai berikut: Apakah kegiatan Lesson Study dapat meningkatkan ketuntasan belajar Fisika Inti bagi mahasiswa program studi Pendidikan Fisika? Untuk memperjelas rumusan masalah tersebut, perlu diajukan pertanyaan-pertanyaan penelitian sebagai berikut:

Bagaimanakah aktivitas mahasiswa dalam pembelajaran Fisika Inti melalui kegiatan Lesson Study?

Bagaimanakah pengelolaan pembelajaran Fisika Inti oleh dosen dalam mengimplementasikan Lesson Study? (3) Bagaimanakah ketuntasan belajar Fisika Inti bagi mahasiswa program studi pendidikan Fisika dengan mengimplementasikan Lesson Study? Tujuan Penelitian (1) Mendeskripsikan aktivitas mahasiswa dalam pembelajaran Fisika Inti melalui kegiatan Lesson Study. (2) Mendeskripsikan pengelolaan pembelajaran Fisika Inti oleh dosen dalam mengimplementasikan Lesson Study. (3) Mendeskripsikan ketuntasan belajar Fisika Inti bagi mahasiswa program studi pendidikan Fisika dengan mengimplementasikan Lesson Study. Adapun urgensi dari penelitian ini adalah: (1) Dosen dapat memilih bentuk kegiatan yang menunjang keprofesionalannya melalui Lesson Study. (2) Sebagai masukan bagi dosen lain bahwa Lesson Study dapat meningkatkan aktivitas dan ketuntasan belajar mahasiswa. (3) Dapat terjalin kerjasama antar dosen matakuliah serumpun (kolegalitas), meningkatkan penguasaan materi dan cara pembelajarannya.

\section{METODE PENELITIAN}

Penelitian ini merupakan penelitian deskriptif kualitatif, dengan memperhatikan: kemajuan aktivitas mahasiswa yang merupakan cerminan pengelolaan pembelajaran oleh dosen serta dampaknya terhadap ketuntasan belajar mahasiswa; kemajuan kinerja dosen; kemajuan kompetensi dosen; sikap dosen di kampus, interaksi antar dosen di kampus; keterlibatan dosen dalam satu rumpun matakuliah.

Dalam penelitian ini terdapat $\mathbf{3}$ (tiga) tahapan yang dilakukan yaitu: tahap pendahuluan (tahap awal), tahap pelaksanaan, dan tahap akhir. Tujuan dan metode/strategi pelaksanaan dari masing-masing tahap diuraikan sebagai berikut.

\section{Tahap pendahuluan (tahap awal)}

Tujuan: Mengumpulkan data dan informasi awal sebelum penelitian dilakukan sebagai baseline dari penelitian. Data dan informasi tersebut berupa: kondisi dan situasi kampus, pemahaman mahasiswa terhadap konsep

8 Fisika Inti, persepsi mahasiswa tentang pembelajaran Fisika Inti, pelaksanaan pembelajaran Fisika Inti.

Metode:

1. Mencari data yang akan dijadikan objek penelitian yang terdiri dari prodi pendidikan Fisika.

2. Menjaring data tentang kondisi dan situasi kampus, yang mendukung interaksi mahasiswa dengan mahasiswa, mahasiswa dengan dosen, dosen dengan dosen dan dosen dengan kaprodi meliputi: ruang belajar, perpustakaan, laboratorium, ruang dosen.

3. Menjaring data tentang penguasaan mahasiswa terhadap konsep pada

Farida Huriawati,dkk 
Fisika Inti (melalui tes tulis). Tes tulis awal ini diberikan kepada mahasiswa untuk mengetahui baseline awal.

\section{Tahap Pelaksanaan}

Tujuan: Meningkatkan keprofesionalan dosen, khususnya dosen dalam pembelajaran

\section{Metode:}

1. Mensosialisasikan tentang konsep dan prinsip Lesson Study kepada: semua yang terlibat dalam kegiatan Lesson Study.

2. Mengimplementasikan kegiatan Lesson Study pada matakuliah Fisika Inti. Kegiatan implementasi tersebut dilakukan sebanyak 4 kali proses pembelajaran. Pada setiap kali implementasi dilakukan kegiatan-kegiatan sesuai prinsipprinsip Lesson Study sebagai berikut:ada tiga tahapan yang harus dilakukan dalam kegiatan Lesson Study, yaitu: merencanakan

(plan), melaksanakan $(d o), \quad$ dan merefleksi (see). Ketiga tahapan ini dilaksanakan secara berkelanjutan.

Ketiga tahapan dalam kegiatan Lesson Studytersebut diuraikan sebagai berikut:

\section{a) Tahap Perencanaan}

Hal-hal yang perlu dilakukan pada tahap perencanaan ini adalah sebagai berikut:

1) mengidentifikasi masalah pembelajaran,

2) menentukan dosen model,

3) menentukan pengamat (observer).

Identifikasi masalah pembelajaran meliputi:

1) materi ajar(harus sesuai dengan kurikulum yang berlaku),

2) teaching material (hands on),

3) strategi pembelajaran (pendahuluan, kegiatan inti, penutup/kegiatan akhir).
Menentukan dosen model dan observer:

1) menentukan siapa yang menjadi model (pengajar) pada saat implementasi pembelajaran. Untuk menjadi dosen model tidak harus dosen senior,

2) menentukan/mengundang observer pada saat implementasi pembelajaran dan juga pada saat refleksi, yang terdiri dari: kelompok dosen serumpun.

\section{b) Tahap Pelaksanaan}

Hal-hal yang perlu dilakukanpada tahap pelaksanaan meliputi:

1) Pertemuan singkat (briefing) yang dipimpin oleh koordinator Lesson Study,

2) Ketua Prodi memberikan penjelasan umum tentang kegiatan Lesson Study yang akan dilakukan,

3) Ketua Prodi memberi kesempatan pada dosen model untuk menjelaskan rencana kegiatan secara singkat,

4) Ketua Prodi mengingatkan kepada Observer agar tidak mengganggu proses belajar mengajar,

5) Observer dipersilahkan mengambil tempat dengan membawa instrumen pengamatan,

6) Dosen model melaksanakan pembelajaran.

Pada tahap pelaksanaan, ada beberapa hal yang harus diketahui oleh Observer, yang antara lain adalah:

1) Informasi tentang Rencana Pelaksanaan Pembelajaran (RPP), yang meliputi materi yang diajarkan.

2) Informasi tentang Lembar Kerja Mahasiswa (LKM)

3) Peta posisi tempat duduk (seting kelas yang digunakan) yang dilengkapi dengan nama-nama mahasiswa. 
Adapun kegiatan yang perlu dilakukan Observer pada tahap pelaksanaan meliputi:

1) Membuat catatan tentang komentar atau diskusi yang dilakukan mahasiswa (yang diamati),

2) Membuat catatan tentang situasi di mana mahasiswa melakukan kerja sama atau tidak melakukan kerja sama,

3) Mencari contoh-contoh bagaimana terjadinya proses konstruksi pemahaman melalui diskusi dan aktivitas belajar yang dilakukan mahasiswa,

4) Membuat catatan tentang variasi metode penyelesaian masalah dari mahasiswa (secara individu atau kelompok), termasuk strategi yang salah.

\section{c) Tahap Refleksi}

Beberapa hal yang perlu diperhatikan pada tahap refleksi antara lain adalah:

1) Dilakukan segera setelah proses belajar mengajar selesai,

2) Paling tidak ada 3 orang observer yang terlibat dalam tahap refleksi.

Langkah-langkah kegiatan dalam

Refleksi adalah sebagai berikut:

1) Ketua kelompok Lesson Study memperkenalkan semua peserta refleksi.

2) Ketua kelompok Lesson Study menyampaikan agenda kegiatan refleksi,

3) Dosen model diberi kesempatan pertama untuk mengomentari proses pembelajaran: kejadian apa yang sesuai harapan, kejadian apa yang tidak sesuai harapan, apa yang berubah dari rencana yang telah disusun,

4) Ketua kelompok Lesson Study memberi kesempatan kepada observer yang menjadi anggota dalam pengembangan rencana pembelajaran untuk memberi komentar tambahan,
5) Ketua kelompok Lesson Study memberi kesempatan kepada notulen untuk merangkum/menyimpulkan hasil diskusi,

6) Ketua kelompok Lesson Study berterima kasih kepada semua yang hadir,

7) Ketua kelompok Lesson Study mengumumkan pelaksanaan Lesson Study berikutnya.

\section{Tahap akhir}

Mengumpulkan data dan informasi akhir setelah penelitian dilakukan sebagai end line dari penelitian. Data dan informasi tersebut berupa: kondisi dan situasi kampus, pemahaman mahasiswa terhadap konsep pada Fisika Inti, persepsi mahasiswa tentang pembelajaran Fisika Inti, pelaksanaan pembelajaran Fisika Inti, dan data ketuntasan belajar matakuliah Fisika Inti mahasiswa program studi Pendidikan Fisika. Dari data yang telah diperoleh dapat dianalisa mengenai capaiannya dan perbaikan serta tindak lanjut berikutnya.

\section{HASIL DAN PEMBAHASAN}

Berdasarkan data tentang tes awal matakuliah Fisika Inti pada mahasiswa prodi pendidikan Fisika (baseline) diperoleh ketuntasan belajar 63,8 \%, dengan nilai tuntas 65 , dengan nilai ratarata 61,86. Sedangkan ketuntasan belajarnya setelah implementasi Lesson Study meningkat menjadi $75 \%$ dengan nilai rata-rata 68,81. Ketuntasan belajar mahasiswa juga ditentukan oleh keprofesionalan dosen dalam melaksanakan kegiatan pembelajaran. Mahasiswa dihimbau untuk mempersiapkan diri dengan belajar terlebih dahulu sebelum pembelajaran di kelas dengan fasilitas modul sebagai sumber belajar.

Interaksi mahasiswa-mahasiswa nampak terjadi peningkatan, dimana mahasiswa saling tukar pikiran dengan diskusi dalam kelompok dengan jumlah 
anggota yang lebih kecil yaitu tiga mahasiswa dalam satu kelompok, yang sebelumnya implementasi interaksinya sangat rendah karena jumlah anggota yang cukup besar diskusi menjadi kurang efektif. Interaksi dosenmahasiswa meningkat, dimana dosen sering berinteraksi dengan mahasiswa dengan mengajukan pertanyaanpertanyaan yang dapat menimbulkan konflik kognitif sehingga memunculkan beberapa alternatif jawaban dari mahasiswa dan sampai pembahasan jawaban yang paling benar. Interaksi dosen-dosen terjadi peningkatan, dimana dosen pengampu matakuliah Fisika Inti bersama sama membahas tentang: materi pembelajaran, pembuatan perangkat pembelajaran, hasil pengamatan (refleksi) pelaksanaan pembelajaran sehingga menumbuhkan rasa kolegalitas, sebelumnya interaksinya belum nampak. Pengelolaan pembelajaran terjadi peningkatan kualitas dibandingkan dengan sebelum implementasi Lesson Study, sebelumnya tidak ada pengamatan pada pelaksanaan pembelajaran sehingga dosen model tidak pernah memperoleh masukan dari dosen lain (pengamat) tentang kekurangan-kekurangan yang terjadi.

\section{Simpulan dan saran}

Simpulan penelitian ialah (1) Interaksi mahasiswa dalam pembelajaran Fisika Inti melalui kegiatan Lesson Study menjadi meningkat.(2) Terjadi peningkatan kualitas pengelolaan pembelajaran Fisika Inti oleh dosen dalam mengimplementasikan Lesson Study. (3) Terjadi peningkatan ketuntasan belajar Fisika Inti bagi mahasiswa program studi pendidikan Fisika dengan mengimplementasikan Lesson Study. Sedangkan saran: Hendaknya setiap matakuliah mengimplementasi Lesson Study agar terjadi peningkatan kualitas pembelajaran.

\section{RUJUKAN}

Sumar Hendrayana. (2006). Strategi Untuk meningkatkan

Keprofesionalan Pendidik. Makalah Seminar Exchange Experience of Lesson Study di UPI Bandung.

Sumar Hendrayana. (2007). Lesson Study : Suatu Strategi Untuk meningkatkan Keprofesionalan Pendidik. Bandung : UPI Press. 

